Khazanah: Jurnal Studi Islam dan Humaniora

ISSN: 0215-837X (p); 2460-7606 (e), Vol. 17 (1), 2019, pp. 137-166

DOI: $10.18592 /$ khazanah.v17i1.2885

Submit : 24/05/2019 Review : 24/06/2019 Publish : 30/07/2019

\title{
INTERNALISASI NILAI PENDIDIKAN MELALUI AKTIVITAS MASYARAKAT SEBAGAI SUMBER BELAJAR ILMU PENGETAHUAN SOSIAL
}

\author{
Bambang Subiyakto \\ Pendidikan IPS FKIP Universitas Lambung Mangkurat \\ bambangsb@ulm.ac.id
Mutiani
Pendidikan IPS FKIP Universitas Lambung Mangkurat mutiani@ulm.ac.id

\begin{abstract}
The research purposes are to describe what educational value is in the lives of the Banjar community in Sungai Rangas Ulu village, Kabupaten Banjar; and to describe the contribution of the educational values of the life of the Banjar community in the Sungai Rangas Ulu village, Kabupaten Banjar, as a source of social sciences learning at junior high school. A qualitative approach is used in this research. The technique of collecting the data are interview, observation and documentation. Data analysis starts from the reduction, presentation, and verification of data. The results shows that the dominance of parents in rural communities seems so clear that makes people feel dependent on the presence of parents or elders in the community. Parents are used as role models for community life. Moreover, educational values that arise from life, namely; religious, ethical and social. The form is in the form of; Religious; dominant religious activity, Ethics; inheritance of cultural values from generation to generation, and Social; manifestation of harmonious relations between owners and cultivators of agricultural land. The contribution of educational values and social cciences learning resources is an integrated form of educational value and Social Sciences learning. The resources of Social Sciences learning must be seen as a unified whole in a learning process. Thus, they are practical and effective in the soul and buman actions and objectively institutionalize in society.
\end{abstract}

Keywords: Educational Values; Role Models; Social Sciences; Learning Resources

Abstrak: Tujuan penelitian ini adalah mendeskripsikan nilai pendidikan dalam kehidupan masyarakat Banjar di Desa Sungai Rangas Ulu Kabupaten Banjar, dan menggambarkan kontribusi nilai-nilai pendidikan dari kehidupan masyarakat Banjar di Desa Sungai Rangas Ulu Banjar sebagai sumber belajar IPS di SMP. Pendekatan kualitatif digunakan dalam penelitian. Teknik pengumpulan data meliputi; wawancara, observasi dan dokumentasi. Analisis data dimulai dari reduksi, presentasi, dan verifikasi 
data. Hasil penelitian menggambarkan dominasi orang tua di masyarakat pedesaan tampak begitu jelas sehingga membuat orang merasa tergantung pada kehadiran orang tua atau orang tua di masyarakat. Orang tua digunakan sebagai panutan bagi kebidupan masyarakat. Nilai-nilai pendidikan yang muncul dari kehidupan, yaitu; agama, etis, dan sosial. Bentuknya dalam bentuk; Agama; aktivitas keagamaan yang dominan, Etika; pewarisan nilai-nilai buday a dari generasi ke generasi, dan Sosial; manifestasi bubungan yang harmonis antara pemilik dan penggarap lahan pertanian. Kontribusi nilai-nilai pendidikan dan sumber belajar pembelajaran sosial adalah suatu bentuk integrasi nilai pendidikan dalam pembelajaran sosial. Sumber belajar pembelajaran sosial harus dilihat sebagai kesatuan yang utuh dalam proses pembelajaran. Sebagai kesimpulan, sumber belajar pembelajaran sosial praktis dan efektif dalam jiwa dan tindakan manusia dan secara objektif dilembagakan dalam masyarakat.

Kata Kunci: Nilai-nilai Pendidikan; Panutan; Sumber Belajar IPS.

\section{Pendahuluan}

Eksistensi sebuah bangsa terwujud melalui penggalian kearifan lokal pada setiap wilayah di negeri ini. Praksis pendidikan pada setiap jenjang harus diselenggarakan secara terprogram dan sistematis mengarah kepada pencapaian tujuan pendidikan nasional. Penggabungan muatan nilai-nilai budaya yang digali dari masyarakat adalah untuk menghasilkan insan Indonesia yang cerdas dan kompetitif serta mampu menghadapi persaingan global. Regulasi pemerintah melalui perubahan kurikulum dari KTSP (Kurikulum Tingkat Satuan Pendidikan) ke Kurikulum 2013 menjelaskan kompetensi yang harus dimiliki oleh peserta didik, yakni memiliki kemampuan berkomunikasi, berpikir jernih dan kritis, kemampuan mempertimbangkan segi moral suatu permasalahan, menjadi warga negara yang efektif, dan toleran terhadap pandangan yang berbeda.

Pendidikan dalam visi global perlu mempersiapkan peserta didik menjadi warga global yang bertanggung jawab dan mampu menjadi agen perubahan (agent of change) dalam memerangi ketidakadilan sebagai dampak negatif globalisasi. ${ }^{1}$ Proses perubahan global yang didukung oleh pengetahuan dan media teknologi melahirkan budaya dunia yang homogen. Pada akhirnya, perubahan itu mengakibatkan hilangnya

${ }^{1}$ Anderson L.W and Krathwohl D.R, Kerangka Landasan untuk Pembelajaran, Pengajaran dan Asesmen: Revisi Taksonomi Pendidikan Bloom (Yogyakarta: Pustaka Pelajar, 2010), 41. 
pengalaman dan pemahaman generasi muda terhadap keragaman budaya. Intinya, terdapat potensi hilangnya arah sebagai bangsa yang memiliki jati diri bangsa; kekhawatiran lenyapnya identitas kultural nasional dan lokal; dan lunturnya semangat patriotism dan nasionalisme.

Kondisi tersebut memberikan gambaran bahwa bangsa memiliki segudang masalah, walaupun secara fisik pembangunan mengalami kemajuan, sebagaimana tergambar dalam Desain Induk Pendidikan Karakter. ${ }^{2}$ Pembangunan nasional dalam segala bidang dilaksanakan sehingga negara mampu kemajuan. Namun di tengah-tengah kemajuan tersebut terdapat dampak negatif, yaitu terjadinya pergeseran terhadap nilai-nilai etika dalam kehidupan berbangsa dan bernegara. Pergeseran sistem nilai ini sangat tampak dalam kehidupan masyarakat dewasa ini, seperti penghargaan terhadap nilai budaya dan bahasa, nilai solidaritas sosial, musyawarah mufakat, kekeluargaan, sopan santun, kejujuran, rasa malu, dan cinta tanah air dirasakan semakin memudar. ${ }^{3}$

Kemajuan menghadapkan masyarakat Indonesia kepada dampak globalisasi dan perkembangan ipteks, serta pergeseran nilai. Dampak ini muncul di tengah kehidupan serta kompeleksitas atau kerumitan sosial dan kesemrautan sosial. Konsep tersebut dapat dipahami sebagai sistem yang kompleks yang terdiri dari berbagai bagian yang berinterkoneksi dengan cara yang rumit sehingga membutuhkan paradigma alternatif untuk bisa memahaminya. Namun hal yang paling penting dari itu semua adalah bahwa pendidikan harus menjadi leading sector. Ada keyakinan jika pendidikan harus menjadi pioner dalam mengatasi berbagai permasalahan bangsa saat ini. ${ }^{4}$

Penggambaran kondisi tersebut berkorelasi terhadap kondisi Pendidikan IPS saat ini. Menurut hasil kajian Pusat Kurikulum

${ }^{2}$ Kemendiknas, Pengembangan Pendidikan Budaya dan Karakter Bangsa (Jakarta: Kementrian Pendidikan Nasional, 2010), 3-4.

${ }^{3}$ Musyarrafah Sulaiman Kurdi, "Evaluasi Implementasi Desain Pendidikan Karakter Berbasis Pendekatan Humanistik," Elementary: Jurnal Ilmiah Pendidikan Dasar 4, no. 2 (November 27, 2018): 125-38, https://doi.org/10.32332/elementary.v4i2.1243.

${ }^{4}$ Roni Faslah, "Pemanfaatan Internet Dalam Pengembangan Konsep Ips Dan Implikasinya Terhadap Pembelajaran Bermakna," Jurnal Ilmiah Econosains 9, no. 2 (2011): 167-70, https://doi.org/10.21009/econosains.0092.07. 
permasalahan Pendidikan IPS, diantaranya sebagai berikut: (1) guru masih berorientasi pada buku teks, tidak mengacu pada dokumen kurikulum; (2) materi belum terintegrasi walaupun judul bukunya "IPS Terpadu"; (3) guru dalam menyusun silabus dan RPP belum banyak memperlihatkan kekhasan pada satuan pendidikannya; (4) Ada suatu kecenderungan pemahaman yang salah bahwa pelajaran IPS adalah pelajaran yang cenderung pada hafalan. Pemahaman seperti ini berakibat pada pembelajaran yang lebih menekankan pada verbalisme. ${ }^{5}$

Sedangkan beberapa kelemahan pembelajaran IPS: (1) kurang memerhatikan perubahan-perubahan dalam tujuan, fungsi, dan peran Pendidikan IPS di sekolah. Tujuan pembelajaran IPS kurang jelas dan tidak tegas (not purposeful); (2) posisi, peran, dan hubungan fungsional dengan bidang studi lainnya terabaikan, informasi faktual lebih tertumpu pada buku paket yang out of date dan kurang mendayagunakan sumbersumber lainnya; (3) lemahnya transfer informasi konsep ilmu-ilmu sosial dan output Pendidikan IPS tidak memberi tambahan daya dan tidak pula mengandung kekuatan (not empowering and not powerful); (4) guru tidak dapat menyakinkan peserta didik untuk belajar Pendidikan IPS lebih bergairah dan bersungguh-sungguh. Peserta didik tidak dibelajarkan untuk membangun konseptualisasi yang mandiri; (5) guru lebih mendominasi (teacher centered), kadar pembelajaran yang rendah dan kebutuhan belajar peserta didik yang tidak terlayani; (6) belum membiasakan pengalaman nilai-nilai kehidupan demokrasi sosial kemasyarakatan dengan melibatkan peserta didik dan seluruh komunitas sekolah dalam berbagai aktivitas kelas dan sekolah dan dalam pertemuan kelas tidak mengagendakan setting lokal nasional dan global khususnya berkaitan dengan struktur sistem sosial dan perilaku kemasyarakatan. ${ }^{6}$

Inovasi-inovasi dalam pembelajaran IPS telah dilakukan melalui eksplorasi sumber belajar IPS dengan memanfaatkan potensi lokal. Potensi lokal dalam pembelajaran IPS bisa dilakukan dengan

5 Puskur Balitbang Depdiknas, Model Pembelajaran IPS Terpadu (Jakarta: Depdiknas, 2007), 46.

${ }^{6}$ Suwarma Al Muchtar, Pendidikan Ilmu Pengetahuan Sosial (Dalam Ilmu dan Aplikasi Pendidikan) (Bandung: PT Imperial Bhakti, 2007), 81. 
memanfaatkan potensi lingkungan sekitar, sehingga peserta didik mampu mewujudkan kesadaran sosial menuju masyarakat demokratis dan bertanggung jawab. ${ }^{7}$ Potensi lokal tidak hanya berupa artefak sebagai bukti dari kearifan lokal masyarakat. Akan tetapi, potensi lokal juga bisa digali melalui aktivitas yang memunculkan nilai yang bermanfaat bagi praktik pendidikan. Sebagai bentuk perbandingan seperti penelitian "Nilai-Nilai Gotong Royong pada Tradisi Bahaul dalam Masyarakat Banjar di Desa Andhika sebagai Sumber Pembelajaran IPS." Hasil penelitian mendeskripsikan bagaimana hubungan emosional masyarakat Banjar bisa direkatkan melalui aktivitas keagamaan yakni bahaul. ${ }^{8}$ Adapun nilai yang terkandung dari aktivitas tersebut memiliki signifikansi dalam pendidikan IPS karena aktivitas bahaul memiliki nilai solidaritas, toleransi, dan peduli sosial sehingga memperkaya sumber belajar IPS di sekolah. ${ }^{9}$

Berbeda dengan penelitian di atas, artikel ini memfokuskan kajian kepada aktivitas masyarakat di Desa Sungai Rangas Ulu Kabupaten Banjar. Pemilihan lokasi Desa Sungai Rangas Ulu didasari oleh pola interaksi antar masyarakat yang rekat satu sama lain. Di samping itu, sebagai kategori masyarakat rural (pedesaan) sungai dijadikan sumber aktivitas kehidupan. Sungai dimanfaatkan tidak hanya untuk memenuhi kebutuhan fisiologis masyarakat dan jalur transportasi, tetapi juga sebagai lokus berkembangnya kebudayaan masyarakat. ${ }^{10}$

Eksplorasi nilai yang terkandung dari aktivitas masyarakat dimaksudkan untuk memperkaya kajian Pendidikan IPS. Dengan

${ }^{7}$ Mutiani Mutiani, "Pemanfaatan Puisi Sebagai Sumber Belajar IPS untuk Menumbuhkan Kesadaran Lingkungan Peserta Didik di Smp Negeri 6 Banjarmasin," Jurnal Pendidikan Ilmu Sosial 24, no. 2 (April 7, 2016), 199-208.

${ }^{8}$ Bambang Subiyakto, Syaharuddin Syaharuddin, dan Gazali Rahman, "NilaiNilai Gotong Royong Pada Tradisi Bahaul Dalam Masyarakat Banjar Di Desa Andhika Sebagai Sumber Pembelajaran IPS," Vidya Karya 31, no. 2 (November 2, 2017), https://ppjp.ulm.ac.id/journal/index.php/JVK/article/view/3993.

${ }^{9}$ Ibid., 3-4

${ }^{10}$ Barnbang Subiyakto dan Djoko Suryo, "Pelayaran Sungai Di Kalimantan Tenggara: Tinjauan Historis Tentang Transportasi Air Abad XIX = Inland Navigation in Southeast Kalimantan: A Historical Study of Water Transportationin The Nineteenth Century," Sosiobumanika 14, no. $2001 \quad$ (2001), http://ilib.ugm.ac.id/jurnal/detail.php?dataId=3518. 
demikian, Pendidikan IPS mampu membentuk peserta didik untuk menyadari dirinya sebagai bagian dari warga negara dunia yang harus memahami orang lain dalam hidupnya. Tentunya hal yang dimaksud dapat diimplementasikan melalui konsepsi manusia sebagai makhluk individu dan sosial yang melekat dalam kehidupan sehari-hari. Berdasarkan penjelasan tersebut maka penggalian nilai pendidikan dari budaya Banjar memiliki peran strategis terhadap proses pembentukan karakter bangsa melalui pengembangan materi IPS dengan menggali nilai-nilai kehidupan masyarakat Banjar Desa Sungai Rangas Ulu Kabupaten Banjar.

\section{Metode}

Kajian ini bertujuan untuk mendeskripsikan kehidupan masyakarat Banjar Desa Sungai Rangas Ulu Kabupaten Banjar. Hasil kajian ini selanjutnya dijadikan sebagai bahan untuk pengembangan sumber belajar Pendidikan IPS pada jenjang SMP/MTs. Berdasarkan fokus penelitian, pendekatan kualitatif dan metode etnografi digunakan pada penelitian. Desain penelitian etnografi dipahami sebagai bagian dari penelitian kualitatif yang memiliki tujuan untuk menggambarkan prosedur, menganalisis, dan menafsirkan budaya kelompok yang terdiri dari pola perilaku, keyakinan, dan bahasa yang berkembang dari waktu ke waktu. ${ }^{11}$ Fokus penelitian etnografi menurut Creswell adalah kebudayaan. Budaya merupakan rangakaian manifestasi perilaku manusia dan keyakinan termasuk bahasa, ritual, struktur ekonomi dan politik, tahap kehidupan, interaksi, dan gaya komunikasi. Penelitian etnografi melibatkan aktivitas belajar mengenai dunia orang yang telah belajar melihat, mendengar, berbicara, berpikir dan bertindak dengan cara yang berbeda. ${ }^{12}$ Oleh karena itu etnografi tidak hanya mempelajari masyarakat, tetapi lebih dari itu, etnografi belajar dari masyarakat.

${ }^{11}$ J. W Creswell, Research Design: Pendekatan Kualitatif, Kuantitatif, dan Mixed (Yogjakarta: Pustaka Pelajar, 2010), 32.

${ }^{12}$ James P Spradley, Metode Etnografi (Yogyakarta: Tiara Wacana, 2007). 21-25. 
Berkenaan dengan pelaksanaan penelitian, dilakukan di Martapura, Kabupaten Banjar tepatnya di Desa Sungai Rangas Ulu. Desa Sungai Rangas Ulu terbagi menjadi 3 (tiga) rukun tetangga (RT), seperti; RT 1, 2, dan 3. Tepatnya pada tanggal 18 s.d. 30 November 2018. Adapun subjek penelitian kualitatif berdasar pada prosedur teknik pemilihan sampel dilakukan secara acak (purposive sampling) dan snowball. Bilamana dalam proses pengumpulan data sudah tidak ditemukan lagi variasi informasi, maka peneliti tidak perlu menambah informan baru. ${ }^{13}$ Karena itu jumlah sampel dalam penelitian kualitatif tidak terbatas, bisa sedikit bisa juga banyak, tergantung tepat tidaknya pemilihan informan kunci dan kompleksitas dan keragaman fenomena sosial yang diteliti. ${ }^{14}$

Subyek penelitian adalah pihak yang berdasarkan berbagai pertimbangan dinilai memiliki kualitas dan ketepatan untuk berperan sebagai subyek penelitian sesuai dengan tujuan penelitian. Kriteria pemilihannya didasarkan pada profesi, pengalaman, kemampuan, wawasan aktual historis dan antisipatoris tentang masalah yang diteliti. ${ }^{15}$ Sampel yang dipilih berfungsi untuk mendapatkan informasi yang maksimum, bukan untuk digeneralisasikan. Berdasarkan penjelasan tersebut, maka subyek dalam penelitian masyarakat yang dianggap memiliki pengetahuan, pemahaman, dan pengalaman tentang fokus dan tujuan penelitian, yakni tentang kehidupan masyarakat Banjar Desa Sungai Rangas Ulu Kabupaten Banjar. Dengan detail narasumber sebagai berikut:

${ }^{13}$ Burhan Bungin, Analisis Data Penelitian Kualitatif (Jakarta: Raja Grafindo Persada, 2008), 51. 2014), 76 .

${ }^{14}$ Sugiyono, Metode Penelitian Kuantitatif Kualitatif dan R\&D (Bandung: Alfabeta,

15 Shirley Agostinho, "Naturalistic Inquiry in E-Learning Research," International Journal of Qualitative Methods 4, no. 1 (March 1, 2005): 13-26, https://doi.org/10.1177/160940690500400102. 
Bambang Subiyakto \& Mutiani

\begin{tabular}{clcl}
\hline No & \multicolumn{1}{c}{ Nama } & Umur & \multicolumn{1}{c}{ Pekerjaan } \\
\hline 1 & Muhammad Aqli & 42 & Kepala Desa (Pembakal) \\
\hline 2 & Saudah & 57 & Ibu Rumah Tangga \\
\hline 3 & Sapnah & 59 & Pedagang \\
\hline 4 & Baihaki & 63 & Petani \\
\hline 5 & Rahmadi & 60 & Petani \\
\hline
\end{tabular}

Tabel 1. Daftar Narasumber

Teknik pengumpulan data dalam penelitian ini, meliputi: (1) wawancara; (2) observasi; dan (3) studi dokumentasi. Teknik analisa data dilakukan secara kualitatif dengan cara mengkategori, mengklasifikasi berdasarkan kaitannya secara logis dan kemudian menafsirkan sesuai dengan permasalahan penelitian. Penelitian ini menggunakan analisa data berdasarkan model Miles and Huberman yaitu dimulai dari: (1) pengumpulan data; (2) reduksi data; (3) penyajian data; (4) penarikan kesimpulan dan verifikasi. ${ }^{16}$ Pasca pengumpulan data, dilakukan beberapa langkah agar proses dan hasil penelitian dapat dipertanggungjawabkan secara ilmiah. Terdapat langkah tentang persoalan verifikasi data, yaitu: (1) Perpanjangan waktu kerja dan observasi (prolonged engagement and persistent observation) yang gigih di lapangan termasuk membangun kepercayaan dengan para partisipan, mempelajari budaya, dan mencek informasi yang salah yang berasal dari distorsi yang dibuat oleh peneliti atau informan.

Di lapangan peneliti membuat keputusan-keputusan apa yang penting atau menonjol untuk dikaji, relevan dengan maksud kajian, dan perhatian untuk difokuskan. (2) Triangulasi (triangulation), adalah menggunakan seluas-luasnya sumber-sumber yang banyak dan berbeda, metode-metode, dari para peneliti, dan teori-teori untuk menyediakan bukti-bukti yang benar (corroborative evidence). Triangulasi dimaksudkan

16 Rhischa Assabet Shilla, Sentot Kusairi, and Arif Hidayat, "nalisis Penguasaan Konsep Hukum Newton tentang Gerak pada Implementasi Pembelajaran Berbasis Scientific Approach disertai Formative Assessment," Jurnal Pendidikan: Teori, Penelitian, dan Pengembangan 3, no. 8 (August 1, 2018): 1089-94, https://doi.org/10.17977/jptpp.v3i8.11485. 
untuk mengurangi kemungkinan terjadinya kesalahan interpretasi. Karena itu, diperlukan prosedur-prosedur yang beragam dalam pengumpulan data hingga mencapai titik jenuh (redundancy of data gathering). (3) Review sejawat (peer review) atau debriefing menyiapkan suatu cek eksternal dari proses penelitian; teman sejawat itu menanyakan pertanyaan-pertanyaan sulit tentang metode, makna dan interpretasi penelitian dari peneliti. (4) Analisis kasus negatif (negative case analysis). Peneliti memperbaiki lagi hipotesis-hipotesis kerjanya selagi penelitian berlangsung berdasarkan atas bukti (evidensi) yang negatif atau tidak pasti (disconfirming evidence). (5) Cek-cek anggota (member checks), peneliti mengumpulkan atau mencari (solicit) pandangan-pandangan para informan tentang kredibilitas dari temuan-temuan dan interpretasiinterpretasi. ${ }^{17}$ Teknik ini ini sangat umum dalam kajian kualitatif, termasuk pengambilan data, analisis, interpretasi, dan kesimpulan-kesimpulan yang kembali kepada para partisipan sehingga mereka dapat mempertimbangkan akurasi dan kredibilitas dari narasi. ${ }^{18}$ Cek anggota dalam hal ini adalah subyek yang terlibat dalam penelitian ini. Dalam pelaksanaannya dapat dilakukan secara informal dengan cara membandingkan antar kelompok subyek penelitian, sedangkan secara formal dengan mengkomunikasikan hasil penelitian sementara kepada beberapa subyek penelitian untuk memeroleh kritik, saran, serta tambahan informasi agar data benar-benar memiliki validitas yang tinggi.

\section{Pembahasan}

Desa Sungai Rangas Ulu adalah salah satu desa dari 13 (tiga belas) desa di Kecamatan Martapura Barat Kabupaten Banjar Propinsi Kalimantan Selatan yang terletak di wilayah Kecamatan Martapura Barat. Desa Sungai Rangas mengenal dua musim yaitu: musim penghujan dan musim kemarau, dimana musim hujan dan musim kemarau silih berganti datang setiap tahun. Adapun penggunaan lahan Desa Sungai Rangas Ulu

${ }^{17}$ J.W. Creswell, Research Design: Pendekatan Kualitatif, Kuantitatif, Dan Mixed. (Yogyakarta: Pustaka Pelajar, 2010), 67.

${ }^{18}$ Nasution, Metode Penelitian Naturalistik Kualitatif (Bandung: Tarsito, 2003), 81. 
meliputi: perumahan dan pekarangan yang umumnya menyebar secara memanjang mengikuti sepanjang tepian sungai Martapura, persawahan terdapat di belakang rumah penduduk, perkebunan, tegal/ladang/kebun serta terdapat rawa/waduk/danau dan lainnya.

Mata pencaharian penduduk desa Sungai Rangas Ulu yang dominan adalah bergerak dibidang pertanian sebanyak 1073 jiwa, sisanya bergerak dibidang PNS/TNI 6 jiwa, swasta sebanyak 158 jiwa, pekerjaan lain 273 jiwa dan yang belum bekerja sebanyak 264 jiwa. Secara lengkap untuk mengetahui keadaan mata pencaharian penduduk desa Sungai Rangas Ulu dapat dilihat pada tabel 2 berikut:

\begin{tabular}{clcc}
\hline No & MataPencaharian & $\begin{array}{c}\text { Jumlah } \\
\text { (Jiwa) }\end{array}$ & $\begin{array}{c}\text { Persentasi } \\
\mathbf{( \% )}\end{array}$ \\
\hline 1 & Petani & 1073 & $60,4 \%$ \\
\hline 2 & PNS/TNI & 6 & $0,33 \%$ \\
\hline 3 & Swasta & 158 & $8,90 \%$ \\
\hline 4 & Pekerjaanlain & 273 & $15,38 \%$ \\
\hline 5 & Belumbekerja & 264 & $14,88 \%$ \\
\hline & $\quad$ Jumlah & 1774 & $100 \%$ \\
\hline
\end{tabular}

Tabel 2. Keadaan Mata Pencaharian Penduduk Desa Sungai Rangas Ulu Kecamatan Martapura Barat Kabupaten Banjar

Sumber: Hasil Pendataan Penduduk Desa Sungai Rangas Ulu Kecamatan Martapura Barat Kabupaten Banjar Tahun 2018

Berdasarkan data pada Tabel 2, mayoritas mata pencaharian adalah pada sector pertanian. Secara umum dilihat pertanian di Desa Sungai Rangas Ulu Kabupaten Banjar termasuk dalam kategori tradisional. Hasil dari pertanian tersebut belum memberikan kontribusi banyak terhadap kesejahteraan masyarakat. Potensi sumber daya yang tersedia di Desa Sungai Rangas Ulu sangat besar, akan tetapi faktor utama yang menjadi penunjang bagi masyarakatnya dalam meningkatkan kehidupan sosial ekonomi mereka masih sangat minim. Hal ini dipengaruhi oleh kurangnya pembangunan infrastruktur. Faktor yang menjadi penyebab mengapa di Desa Sungai Rangas Ulu belum ada pembangunan infrastruktur jalan secara menyeluruh adalah karena jalan yang biasa 
menjadi akses bagi masyarakatnya adalah kawasan hutan dan sungai. Oleh karena itu, masyarakat membutuhkan pembangunan infrastruktur jalan. Pembangunan jalan dimaksudkan untuk menunjang peningkatan kehidupan ekonomi masyarakat Desa Sungai Rangas Ulu Kabupaten Banjar. Berdasarkan pengamatan awal kondisi infrastruktur jalan yang berada di Desa Sungai Rangas Ulu Kabupaten Banjar yang proses pembangunannya masih berupa pengerasan. Berbeda dengan jalan utama yang sudah diaspal, pembangunan infrastruktur di lingkungan sekitar masih berada pada tahap awal pembangunan; bahkan untuk WC sebagai fasilitas umum masih belum dibuat.

\section{Identifikasi Nilai Pendidikan pada Aktivias Kehidupan Masyarakat Banjar Desa Sungai Rangas Ulu Kabupaten Banjar}

Pada kehidupan masyarakat nilai dipahami sebagai sesuatu untuk memberikan tanggapan atas perilaku, tingkah laku, dan segala sesuatu yang berkaitan dengan aktivitas masyarakat baik secara kelompok maupun individu. Nilai yang muncul tersebut dapat bersifat positif apabila akan berakibat baik, namun akan bersifat negatif jika berakibat buruk pada obyek yang diberikan nilai. ${ }^{19}$ Nilai dapat dipahami sebagai bentuk metafisis, meskipun berkaitan dengan kenyataan konkret. Nilai tidak dapat kita lihat dalam bentuk fisik, sebab nilai adalah harga sesuatu hal yang harus dicari dalam proses manusia menanggapi sikap manusia yang lain.

Nilai pada dasarnya sudah ada dan terkandung dalam sesuatu, sehingga dengan pendidikan membantu seseorang untuk dapat menyadari dengan mencari nilai-nilai mendalam dan memahami kaitannya satu sama lain serta peranan dan kegunaan bagi kehidupan. Nilai dan kebudayaan tidak bisa dilepaskan satu sama lain. Kebudayaan merupakan suatu konsep yang luas yang di dalamnya tercakup adanya sistem dari pranata nilai yang berlaku, termasuk tradisi yang

${ }^{19}$ Yanwar Pribadi, "Dinamika Hubungan Sosial-Keagamaan Pada Masyarakat Nelayan Di Karangantu Banten," TEOSOFI: Jurnal Tasawuf Dan Pemikiran Islam 7, no. 1 (June 2, 2017): 199-224, https://doi.org/10.15642/teosofi.2017.7.1.199-224. 
mengisyaratkan makna pewarisan norma-norma, kaidah-kaidah, adat istiadat dan harta-harta kultural. ${ }^{20}$ Kebudayaan yang di dalamnya terdapat nilai perlu upaya pelestarian melalui pendidikan. Pendidikan didefinisikan lugas sebagai usaha sadar yang dilakukan oleh keluarga, masyarakat dan pemerintah melalui bimbingan, pengajaran dan latihan yang berlangsung di dalam sekolah maupun diluar sekolah untuk mempersiapkan peserta didik agar dapat menyesuaikan di berbagai lingkungan. ${ }^{21}$

Pendidikan sebagai proses pembelajaran untuk mencapai kedewasaan, baik dalam perilaku maupun kehidupan sehari-hari, mendorong seseorang menjadi warga yang baik, sadar tehadap tata cara hidup bermasyarakat. Dengan demikian dapat diketahui bahwa pendidikan merupakan bagian dari proses pembudayaan dan merupakan upaya masyarakat untuk kelangsungan tradisinya. Pendidikan adalah sebuah proses melalui kebudayaan yang mengontrol masyarakat. Nilai pendidikan adalah sikap dan tingkah laku yang berguna untuk kemanusiaan yang tidak lepas dari nilai-nilai kebudayaan yang memiliki norma-norma, adat istiadat dan peraturan yang dijunjung tinggi oleh lapisan masyarakat suatu bangsa didasarkan atas prinsip-rinsip, cita-cita dan filsafat yang berlaku dalam masyarakat. Nilai pendidikan yang dimaksud adalah sesuatu tolak ukur yang menjadi dasar untuk mengembangkan potensi diri, landasan spiritual untuk mencapai kedewasaan baik dalam perilaku maupun kehidupan sehari-hari. Sejalan dengan hasil penelitian yang dilakukan di Kelurahan Sungai Rangas Ulu, nilai pendidikan muncul dari aktivitas keseharian masyarakat. Bentukbentuk nilai positif tergambar dalam kehidupan masyarakat Desa Sungai Rangas Ulu.

20 "Perubahan, Kebudayaan, dan Agama: Perspektif Antropologi Kekuasaan | E-Jurnal Kajian Budaya (Online Journal of Cultural Studies)," accessed July 30, 2019, https://ojs.unud.ac.id/index.php/kajian/article/view/13874.

21 Tilaar H.A.R, Paradigma Baru Pendidikan Nasional (Jakarta: Rineka Cipta, 2000), 56-58. 


\section{Nilai Religius}

Nilai religius merujuk kepada kepatuhan umat terhadap penciptaNya. Religi merupakan suatu kesadaran yang menggejala secara mendalam dalam lubuk hati manusia. Religius melihat aspek di lubuk hati, getaran nurani pribadi, totalitas kedalaman pribadi manusia. Religi tidak hanya menyangkut segi kehidupan secara lahiriah melainkan juga menyangkut keseluruhan diri pribadi manusia secara total dalam integrasinya hubungan ke dalam keesaan Tuhan. Nilai-nilai religius bertujuan untuk mendidik agar manusia lebih baik menurut tuntunan agama dan selalu ingat kepada Tuhan. Nilai religius dalam seni bersifat individual dan personal. Religi lebih pada hati, nurani, dan pribadi manusia itu sendiri. Nilai religius yang merupakan nilai kerohanian tertinggi dan mutlak serta bersumber pada kepercayaan atau keyakinan manusia. Berkenaan dengan pernyataan tersebut, Menurut Sapnah (59) menggambarkan bagaimana aktivitas religius masyarakat sekitar.

Penduduk di sini beisi kegiatan keagamaan yasinan lakian dan binian, mun acara yasinan lakian diadakan malam hari setiap malam Rabu, mun yasinan binian diadakan imbah sambahyang ashar setiap hari Jum'at. Seminggu sekali yasinan dilaksanakan secara bergiliran di rumah nang umpat. Mun biayanya sesuai kesepakatan bersama anggota nang umpat dan dibayar saat acara (Penduduk memiliki kegiatan keagamaan berupa pengajian (yasinan) yang dikhususkan untuk laki-laki dan wanita. Untuk laki-laki dilaksanakan pada hari selasa malam dan setelah hari jum'at sore. Setiap minggu diadakan pengajian secara bergiliran di rumah anggota pengajian dan besaran biaya sesuai kesepakatan anggota dan dibayar saat pelaksanaan).

Kegiatan yasinan laki-laki dilakukan setiap hari Selasa setelah shalat Isya/malam Rabu. Adapun yasinan perempuan diadakan setelah shalat Ashar setiap hari Jum'at. Kegiatan tersebut dilaksanakan satu kali dalam seminggu secara bergiliran. Adapun anggota yasinan biasanya warga masyarakat setempat yang terdiri dari beberapa keluarga/per RT di Desa Sungai Rangas Ulu. Yasinan biasanya dilaksanakan untuk pertama kali di rumah ketua kelompok. Adapun penentuan yang kena giliran minggu 
depan, dilakukan dengan cara bekuncang (undi). Pengundian dilakukan dengan cara dikuncang (dalam Bahasa Banjar) menggunakan botol yang di dalamnya terdapat sejumlah nama anggota. Nama anggota yang keluar dalam pengundian, maka di tempat dialah yasinan akan dilaksanakan. Biasanya anggota juga boleh meminta kepada ketua agar yasinan selanjutnya dilakukan di rumahnya. Permintaan ini biasanya dilakukan karena ada kegiatan bersamaan seperti melaksanakan tasmiyah atau haulan keluarga.

Biaya untuk melaksanakan kegiatan yasinan dilakukan dengan iuran dari para anggota. Para anggota membayar sejumlah uang yang telah disepakati bersama untuk dibayar. Pembayaran iuran dilakukan setiap kali kegiatan yasinan dilakukan. Jadi, setiap anggota membawa sejumlah uang untuk dibayarkan ketika kegiatan yasinan dilakukan di rumah penyelenggara. Pembakal (Kepala Desa) Sungai Rangas Ulu juga Aqli (42) menambahkan informasi mengenai kegiatan religius yang dilakukan masyarakat "Kegiatan keagaman yang dilakukan tidak hanya didominasi golongan tua. Pun golongan tua rajin menghadiri kegiatan tersebut". Pernyataan ini menegaskan bagaimana bentuk ketekunan untuk beribadah agama tidak dipandang sebagai tuntutan formal melainkan sebuah kebutuhan. Khususnya pada momen-momen hari besar keagamaan contohnya bulan Maulid (Rabiul Awal). Berikut gambaran kegiatan keagamaan yang dilaksanakan.
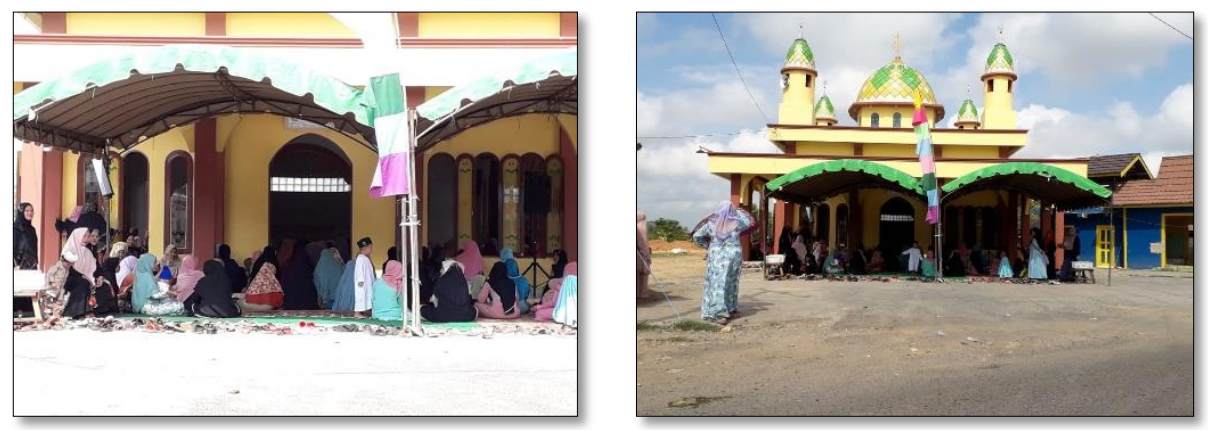

Gambar 1. Aktivitas Keagamaan di Kelurahan Sungai Rangas Ulu Sumber: Dokumentasi Pribadi (Desember, 2018) 
Dari apa yang telah dijelaskan, tampak beberapa nilai kebaikan yang ditujukkan oleh masyarakat Desa Sungai Rangas Ulu. Nilai yang muncul dalam penjelasan tersebut adanya sikap religius. Sikap religius tergambarkan dengan adanya kegiatan yasinan oleh masyarakat. Yasinan yang diselenggarakan oleh masyarakat sebagai kegiatan rutin setiap minggu dan partisipasi di kegiatan keagamaan Islam. Keseluruhan bentuk perilaku adalah perwujudan totalitas tingkah laku manusia dalam kehidupan sehari-hari yang dilandasi dengan iman kepada Allah.

\section{Etika}

Keberadaan etika memfokuskan pada perihal yang dianggap baik dan benar. Dalam pembahasan mengenai perilaku baik dan benar itu, keberadaan moral sebagai hal yang mendasar sebagai prinsip untuk berperilaku. keberadaan etika fokus pada nilai-nilai moral yang terkait. Selain itu, melihat lebih jauh akan keberadaan etika dan moral tersebut, yang pada dasarnya menjadi sebuah penuntun individu dalam berperilaku, tidak dapat dipungkiri merupakan sebuah produk hasil dari satu budaya. Pada bentuk etika kedua ini terdapat penekanan pada konsep moral yang dikembangkan oleh Gilligan yang berorientasi pada kepedulian serta fokus pada pendekatan kebudayaan dalam memahami konsep kepedulian itu sendiri. Berkenaan dengan perpaduan pendekatan kebudayaan dan kaitannya dengan konsep kepedulian, kehidupan masyarakat Desa Sungai Rangas Ulu sangat erat dengan cerita mistis "buaya". Saudah (57) menambahkan:

Masyarakat di sini jua pecaya bahwa ada buaya penunggu sungai. Buaya itu disebut sebagai buaya kuning/buaya gaduban. Jadi, datu-datu bahari menggaduh buaya supaya mun sidin betagihan hutang dan yang kada hakun membayar, maka bisa dikaluarkan sidin buayanya untuk menggaratak orang nang bahutang. Karena orang bahari tu mun betagiban pakai jukung atau kelotok. Buaya tadi diwariskan secara turun temurun, nang kana gilirannya maka harus memakaninya setabun sekali, dengan menyediakan beras lakatan lawan bintalu. Munnya kada hakun memakani maka nang 
kana warisnya bisa kesurupan menyarupai tingkah laku buaya dan bisa batajun ka sungai (masyarakat di sini juga percaya bahwa buaya yang "hidup" di sungai disebut buaya kuning atau buaya yang sengaja dipelihara. Jadi nenek moyang "pelihara" buaya diniatkan untuk menagih hutang. Jika yang berhutang tidak mau bayar, maka buaya akan muncul ke permukaan dan berenang menuju tepian sungai. Hal ini juga dikarenakan orang dulu, menagih hutang menggunakan perahu. Buaya diwariskan secara turun temurun. Yang memelihara diwajibkan untuk memberi makan setiap sekali setahun. Jika lalai hal ini bisa membuat keluarga tersebut kesurupan dan bertingkah layaknya buaya hingga terjun ke sungai).

Masyarakat Desa Sungai Rangas Ulu masih percaya dengan adanya buaya peliharaan yang mendiami di dalam sungai. Biasanya masyarakat tersebut menyebutnya dengan nama buaya kuning/peliharaan nenek moyang. Berdasarkan cerita tersebut buaya yang jadi peliharaan nenek moyang tadi digunakan untuk menagih hutang. Sungai dijadikan sebagai jalur transportasi masyarakat Desa Sungai Rangas Ulu untuk melakukan aktivitas sehari-hari. Nenek moyang mereka ketika ingin menagih hutang menggunakan sampan/perahu bermesin diesel. Ketika orang yang berhutang kepada nenek moyang mereka tidak ingin membayar, maka bisa dimunculkan mereka buaya kuning/peliharaan sebagai tanda menakuti orang yang berhutang.

Hadirnya buaya kuning dimaksudkan untuk memberikan pola kepada kehidupan masyarakat sehingga tidak menunda janji (hutang). Oleh karena itu, sebenarnya buaya kuning/peliharaan tadi tidak berbahaya bagi masyarakat yang beraktivitas di sungai. Buaya tersebut merupakan jelmaan dari makhluk gaib yang dipercayai masyarakat. Buaya diwariskan secara turun temurun dari nenek moyang sampai ke anggota keluarga berikutnya. Anggota keluarga yang mendapatkan warisan untuk meneruskan pemeliharaan buaya tersebut harus memberi makan buaya satu kali setahun. Makanan yang disajikan untuk memberi makan buaya haruslah terbuat dari beras ketan yang dimasak dengan tambahan lauk telur ayam ataupun bebek. Anggota keluarga yang tidak memberi makan, 
maka akan mengalami gangguan dari makhluk gaib jelmaan buaya tersebut. Mereka akan mengalami kerasukan oleh makhluk gaib, sehingga tingkah lakunya seperti seekor buaya.
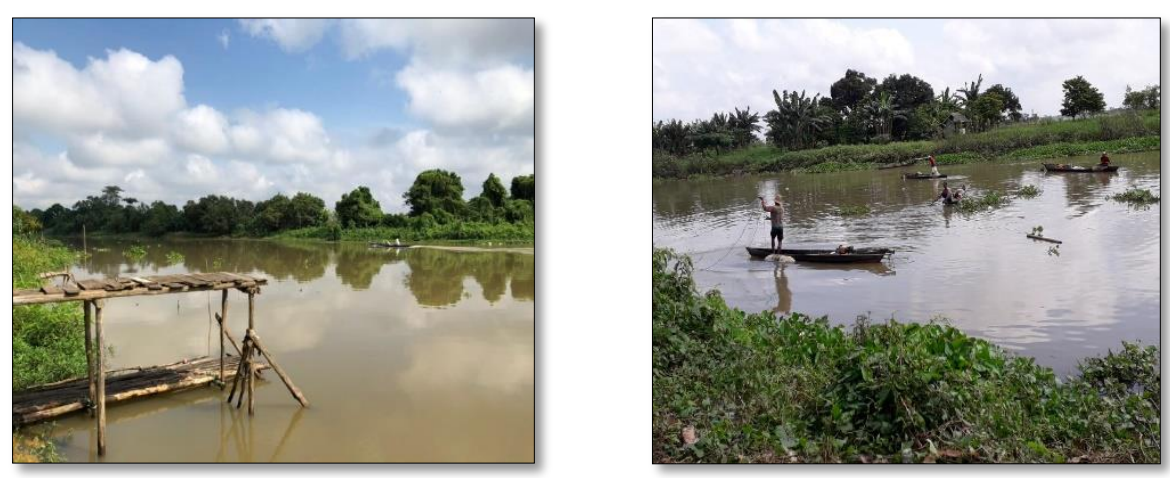

Gambar 2. Kondisi Sungai Rangas

Sumber: Dokumentasi Pribadi (Desember, 2018)

Gambar 3 di atas menggambarkan bagaimana kondisi fisik lingkungan Sungai Rangas Ulu. Kondisi yang masih memungkinkan munculnya fauna; ikan air tawar (gabus, papuyu, lais, patin, nila, dsb.) Kondisi lingkungan fisik yang demikian juga mempengaruhi pandangan masyarakat tentang makhluk mistis (buaya). Penjelasan Saudah (57) memberikan gambaran tentang kepercayaan masyarakat Sungai Rangas Ulu. Sekali lagi, dari gambaran tersebut nampak nilai religius masyarakat Sungai Rangas Ulu percaya terhadap makhluk gaib. Makhluk gaib tersebut digambarkan mereka dengan bentuk seekor buaya kuning yang telah dipelihara secara turun temurun oleh anggota keluarga. Kepercayaan terhadap makhluk gaib dipandang menjadi karakteristik dari segala sesuatu yang religius dengan sebutan konsep supernatural. Konsep supernatural merupakan tatanan hal ihwal berada di luar kemampuan pemahaman kita, dunia misteri, yang tidak bisa diketahui atau ditangkap akal serta diserap pancaindera. Agama dipandang menjadi semacam 
spekulasi terhadap segala sesuatu yang ada di luar sains atau akal sehat pada umumnya. ${ }^{22}$

Ahli Antropologi periode awal memandang sebaliknya. Konsep percaya kepada berpengaruhnya supernatural beings, menurut Tylor, "dimulai dengan kepercayaan kepada animism". Animisme merupakan kekuatan gaib yang punya wujud tersendiri, seperti tuhan, roh nenek moyang, dan jin. Demikian juga menurut Weber, "kepercayaan kepada yang gaib ini sangat fungsional untuk kehidupan sehari-hari yang natural, material, empirik, dan rasional". ${ }^{23}$ Kepercayaan terhadap makhluk gaib merupakan wujud sikap religius dari seseorang terhadap adanya Allah SWT. Sikap religius tersebut sesuai dengan keadaan masyarakat setempat di sana yang mayoritas penduduknya beragama Islam. Adapun sikap tersebut akan sangat bertentangan, jikalau mereka meminta suatu keselamatan dan perlindungan terhadap makhluk gaib. Seharusnya permintaan akan keselamatan dan perlindungan hanyalah kepada Allah SWT semata.

Etika pada dasarnya mengarahkan pada keberadaan satu aturan yang erat kaitannya dengan keberadaanmoral yang tidak dapat terlepas dari keberadaan budaya yang berada di sekitarnya. Penekanan etika yang berbasis community ini mengarahkan pada kelekatan hubungan yang mengarahkan pada bentuk harmoni, pelaksanaan tugas, menghormati, serta kepatuhan. Hal tersebut sejalan dengan hasil penelitian yang sudah dilakukan pada masyarakat Kelurahan Sungai Rangas Ulu bahwa nilai etika mengikat masyarakat untuk menjalani kepatuhan dalam bermasyarakat.

22 Burhanuddin Abdullah, Radiansyah Radiansyah, and Ali Akbar, "PENDIDIKAN KARAKTER DI MADRASAH ALIYAH NEGERI (MAN) 2 BANJARMASIN," INFERENSI: Jurnal Penelitian Sosial Keagamaan 9, no. 2 (December 1, 2015): 537-60, https://doi.org/10.18326/infsl3.v9i2.537-560.

23 Agus Bustanuddin, Agama dalam Kebidupan Manusia: Pengantar Antropologi Agama (Jakarta: Grafindo Persada, 2006), 25. 


\section{Sosial}

Nilai diartikan sebagai harga (taksiran harga), ukuran, dan perbandingan dua benda yang dipertukarkan. Nilai juga bisa berarti angka kepandaian (nilai ujian, nilai rapor), kadar, mutu, dan bobot. Nilai mengandung pengertian yang lebih luas dari pada pengertian sehari-hari. Nilai merupakan sesuatu yang baik, yang diinginkan, yang dicita-citakan, dan dianggap penting oleh warga masyarakat. Nilai sosial adalah segala sesuatu yang dianggap baik dan benar, yang diidam-idamkan masyarakat. Agar nilai-nilai sosial itu dapat tercipta dalam masyarakat, maka perlu diciptakan norma sosial dengan sanksi-sanksi sosial.

Nilai sosial merupakan penghargaan yang diberikan masyarakat kepada segala sesuatu yang baik, penting, luhur, pantas, dan mempunyai daya guna fungsional bagi perkembangan dan kebaikan hidup bersama. Nilai-nilai sosial memengaruhi perkembangan pribadi seseorang, baik positif maupun negatif. Adanya pengaruh yang berbeda akan membentuk kepribadian individu yang berbeda pula. Nilai yang baik akan membentuk pribadipribadi yang baik, begitupun yang sebaliknya. Contohnya orang yang hidup dalam lingkungan yang lebih mengutamakan kepentingan individu daripada kepentingan kelompok mempunyai kecenderungan membentuk pribadi masyarakat yang egois dan ingin menang sendiri. Sehubungan dengan bentuk nilai sosial yang bersifat positif muncul pada aktivitas sosial ekonomi. Hal ini disampaikan oleh Baihaki (63) bahwa:

Kebiasaan masyarakat sini banyak bertani mun sudah datang musim batanam. Ada yang manggawi sawahnya saurang ada jua yang meambil upah menanam di sawah ampun kaluarga dengan cari bagi hasil kena mun imbah mangatam. Kabiasaanya orang kampung sini bila musim tanam bubannya "beandipan", yaitu bagantian menanami banih tiap sawah. Jadi, pina rakat orang bahari tu mun batanamnya, biar lakas tuntung (Kebiasaan masyarakat di sini banyak yang bertani. Jika sudah masuk musim bercocok tanam ada yang mengerjakan sendiri ada juga yang pekerja paruh waktu yang dibayar. Bagi masyarakat 
sekitar pola bercocok tanam bergiliran tiap sawahnya. Dengan demikian, penanaman sawah akan lebih merata dan cepat selesai.

Aktivitas masyarakat Desa Sungai Rangas Ulu pada umumnya sebagai petani di sawah. Sawah di daerah tersebut merupakan rawa lebak. Rawa lebak memerlukan penentuan musim tanam yang cocok untuk pertanaman padi. Petani mulai membersihkan lahannya saat air di sawah mulai surut, biasanya diakhir-akhir musim penghujan. Ketika air mulai surut petani segera mengelola sawah-sawah. Tahapan-tahapannya: (1) Barimba, atau membersihkan rumput atau tanaman yang tumbuh lebat di areal baruh, hal ini juga biasanya diawali dengan menyemprotkan herbisida, guna memudahkan barimba.

Rumput hasil barimba ini bisa dimanfaatkan sebagai pembuat Galang atau pembatas areal, (2) Biasanya ditengah-tengah barimba, petani akan membersihkan areal seluas karpet/salumbah tikar, guna manaradak. Manaradak adalah menyemai benih padi di area salumbah tikar, sedangkan maandal menyemai padi secara beraturaan dengan cara membuat lubanglubang sehingga tumbuhnya teratur dan rapi, (3) Setelah areal bersih dari rumput dan benih hasil taradakan/andalan sudah tumbuh dengan bagus, maka proses penanaman dilakukan dengan cara, membuat lubang dengan cara menancapkan kayu ketanah, kemudian ditanami padi yang sudah dicabut dengan akar-akarnya, proses ini disebut mamacak, (4) Setelah selesai mamacak, kemudian rumput yang tumbuh di sekitar tanaman padi akan dibersihkan, dan (5) Buah Padi maurai dan masak, proses selanjutnya adalah memotong padi, dengan cara mangatam padi dengan Ranggaman/alat potong padi tradisional yang terbuat dari kayu dan silet, atau juga dengan cara maharit/memotong dengan arit atau sabit.

Proses penanaman/mamacak benih padi dan memanen padi di areal persawahan. Masyarakat Sungai Rangas Ulu melakukannya dengan kearifan lokal setempat yang dinamakan "Beandipan". "Beandipan" merupakan proses menanam ataupun memanen padi secara bergantian di setiap sawah milik masyarakat. Penanaman dan pemanenan padi secara "beandipan" biasanya dimulai dari sawah paling ujung sebelah kanan. Mereka melakukannya secara suka rela dari setiap anggota masyarakat. 
Penanaman padi dengan cara "beandipan" tentunya akan mempercepat proses pengerjaannya. Penjelasan tersebut memberikan gambaran tentang keeratan sikap kekeluargaan dari masyarakat setempat. Mereka saling bahu-membahu dalam proses penanaman dan pemanenan sawah. Dengan demikian, dapat diperoleh berbagai nilai yang tergambar dalam kehidupan bermasyarakat Desa Sungai Rangas Ulu. Sikap berkerja keras perlu dilakukan dalam pertanian. Kerja keras artinya melakukan suatu usaha atau pekerjaan secara terus menerus tanpa mengenal lelah. Kerja keras juga dapat diartikan suatu tindakan atau perbuatan yang dilakukan dengan sungguh-sungguh dan serius sampai tercapai suatu tujuan.

Agama Islam mengajarkan umatnya agar selalu bekerja keras dalam menjalankan kehidupannya di muka bumi ini. Segala sesuatu yang dilakukan tidak dengan kerja keras, hasilnya tidak akan sempurna. Sebaliknya, seberat apa pun suatu pekerjaan jika dilakukan dengan sungguh-sungguh, niscaya hasilnya akan dapat diraih dengan baik. Seorang petani perlu bekerja keras dalam mengelola sawah. Proses yang panjang dan sangat lelah, seorang petani perlu bekerja keras agar hasil tanaman padinya bagus. Dimulai dengan membersihkan sawah dari rumput dan tanaman liar, menyemai benih, menanamnya sampai dengan memanen hasil padi.

Sikap tolong-menolong juga tercermin dalam aktivitas masyarakat Desa Sungai Rangas Ulu. Masyarakat melaksanakan penanaman padi bersama-sama dengan pembagian tugas yang merata. Ketika panen masyarakat ikut juga berpartisipasi dengan baik, begitupun pemilik lahan. Nilai dalam tolong-menolong tentunya mengarah pada kebersamaan masyarakat dalam melaksanakan peran dan tugasnya. Tolong-menolong menjadi bagian dari pedoman hidup tentunya memberikan makna yang baik disetiap kegiatan. Masyarakat dapat merasakan kebersamaan yang kuat dengan adanya tolong menolong. Selain memberikan makna kebersamaan, tolong menolong juga memberikan nilai kebahagiaan, ketika satu masyarakat mendapat musibah masyarakat lain akan dengan sadar membantu dan memberikan pertolongannya tanpa harus diminta. 


\section{Kontribusi Nilai Pendidikan Kehidupan Masyarakat Banjar Desa Sungai Rangas Ulu Kabupaten Banjar sebagai Sumber Belajar IPS}

Sumber belajar mencakup apa saja yang dapat digunakan untuk membantu tiap orang untuk belajar dan manampilkan kompetensinya. Sumber belajar meliputi, pesan, orang, bahan, alat, teknik, dan latar. ${ }^{24}$ Pada hakikatnya sumber belajar begitu luas dan kompleks, lebih dari sekedar media pembelajaran. Segala hal yang sekiranya diprediksikan akan mendukung dan dapat dimanfaatkan untuk keberhasilan pembelajaran dapat dipertimbangkan menjadi sumber belajar. Dengan pemahaman ini maka guru bukanlah satu-satunya sumber tetapi hanya salah satu saja dari sekian sumber belajar lainnya.

Berbagai jenis sumber belajar Hendaknya dipandang sebagai satu kesatuan yang utuh dalam sebuah proses pembelajaran. Semua jenis sumber belajar yang memang sesuai, perlu dipertimbangkan demi tercapainya pembelajaran lebih baik. Dengan demikian diharapkan akan berdampak positif terhadap hasil pembelajaran. Proses pembelajaran yang dilakukan adalah dengan pendekatan hafalan (kognitif), lebih ditekankan bagaimana memperoleh nilai yang bagus, sedangkan bagaimana dampak mata pelajaran terhadap perubahan perilaku tidak diperhatikan. Sehingga terdapat kesenjangan antara pengetahuan moral (cognition) dan perilaku (action). Misal, semua orang pasti tahu bahwa berbohong dan korupsi itu salah dan melanggar ketentuan agama, tetapi banyak sekali orang yang tetap melakukannya. Oleh karena itu, diperlukan nilai praktis yang bisa diaplikasikan.

Nilai pendidikan dan praktis aktivitas masyarakat Desa Sungai Rangas Ulu memiliki kontribusi positif. Nilai pendidikan dan sumber belajar IPS bersifat praktis dan efektif dalam jiwa dan tindakan manusia serta melembaga secara objektif di dalam masyarakat. Implikasi nilai merupakan realitas abstrak. ${ }^{25} \mathrm{Hal}$ ini dirasakan dalam diri kita masing-

${ }^{24}$ Moh Iqbal Assyauqi, "Pengembangan Media Pada Pembelajaran Kosa Kata Bahasa Arab Berbasis Komputer Menurut Konsep Teknologi Pembelajaran," Jurnal Al Maqayis 2, no. 1 (September 26, 2014), https://doi.org/10.18592/jams.v2i1.186.

25 Agus Zaenul Fitri, Pendidikan Karakter Berbasis Nilai dan Etika di Sekolah (Yogyakarta: Ar-Ruzz Media, 2012), 27-33. 
masing sebagai daya pendorong atau prinsip-prinsip yang menjadi pedoman dalam hidup. Nilai yang menjadi sesuatu yang abstrak dapat dilacak dari tiga realitas sebagai berikut:

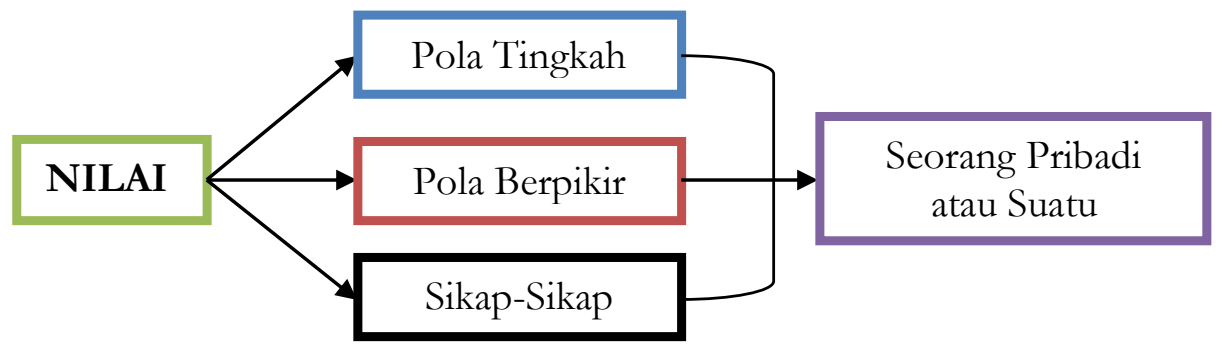

Gambar 4. Tiga Realitas dari Nilai

Nilai-nilai moral yang sebaiknya diajarkan di sekolah adalah kejujuran, keadilan, toleransi, kebijaksanaan, disiplin diri, tolong menolong, peduli sesama, kerjasama, keberanian, dan sikap demokratis. Nilai-nilai yang dikembangkan dalam pendidikan budaya dan karakter bangsa diidentifikasi dari sumber-sumber: ${ }^{26}$

1. Agama: masyarakat Indonesia adalah masyarakat beragama, maka nilai-nilai pendidikan budaya dan karakter bangsa harus didasarkan pada nilai-nilai dan kaidah yang berasal dari agama.

2. Pancasila: negara kesatuan Republik Indonesia ditegakkan atas prinsipprinsip kehidupan kebangsaan dan kenegaraan yang disebut Pancasila. Artinya, nilai-nilai yang terkandung dalam Pancasila menjadi nilai-nilai yang mengatur kehidupan politik, hukum, ekonomi, kemasyarakatan, budaya dan seni. Pendidikan budaya dan karakter bangsa bertujuan mempersiapkan peserta didik menjadi warga negara yang lebih baik, yaitu warga negara yang memiliki kemampuan, kemauan, dan menerapkan nilai-nilai Pancasila dalam kehidupannya sebagai warga negara.

3. Budaya: sebagai suatu kebenaran bahwa tidak ada manusia yang hidup bermasyarakat yang tidak didasari oleh nilai-nilai budaya yang diakui masyarakat itu. Nilai-nilai budaya itu dijadikan dasar dalam pemberian

${ }^{26}$ Thomas Lickona, Character Matters (Jakarta: PT. Bumi Aksara, 2012), 79-88. 
makna terhadap suatu konsep dan arti dalam komunikasi antar anggota masyarakat itu.

4. Tujuan Pendidikan Nasional: tujuan pendidikan nasional memuat berbagai nilai kemanusiaan yang harus dimiliki warga Indonesia. Oleh karena itu, tujuan pendidikan nasional adalah sumber yang paling operasional dalam pengembangan pendidikan budaya dan karakter.

Ilmu pengetahuan sosial memiliki tujuan untuk mengembangkan pengetahuan, sikap, dan keterampilan sosial dalam bentuk konsep dan pengalaman belajar yang dipilih atau diorganisasikan dalam rangka kajian ilmu sosial. Pendidikan IPS merupakan kajian mengenai manusia dengan segala aspeknya dalam sistem kehidupan bermasyarakat. ${ }^{27}$ Ilmu Pengetahuan Sosial mengkaji bagaimana manusia bersama diantara sesamanya dilingkungan sendiri, dengan tetangganya, bagaimana mereka bergerak, bagaimana mereka untuk memenuhi kebutuhan kehidupannya, dan sebagainya. Singkatnya, yang menjadi bahan kajian Ilmu Pengetahuan Sosial adalah keseluruhan tentang manusia. ${ }^{28}$

Tujuan diajarkannya IPS di sekolah adalah untuk memperlengkapi peserta didik dengan pengetahuan, keterampilan, sikap, dan nilai-nilai agar dengan ini mereka dapat mengenali dengan baik berb agai permasalahan sosial kemasyarakatan yang ada disekelilingnya. ${ }^{29}$ Diharapkan pula dengan ini peserta didik dapat merumuskan dan memilih alternatif pemecahan masalah melalui proses pengambilan keputusan, yaitu alternatif pemecahan masalah paling tepat baik bagi dirinya sendiri maupun bagi orang lain. Adapun pedoman pembelajaran IPS sehingga pembelajaran IPS memberikan hasil yang maksimal satu diantaranya adalah berbasis nilai. ${ }^{30}$ Pembelajaran lebih ditekankan pada pengembangan ide-ide yang penting dalam memahami, mengapresiasikan

${ }^{27}$ Numan Somantri, Pembaharuan Pendidikan IPS (Bandung: Rosdakarya, 2001), 67-71.

28 Alma Buchari, Pembelajaran Studi Sosial (Bandung: Alfabeta, 2015), 7.

${ }^{29}$ Sapriya. Pendidikan IPS Konsep dan Pembelajaran (Bandung: Remaja Rosdakarya, 2009), 57.

30 Abdul Azis Wahab, Metode Dan Model-Model Mengajar Ilmu Pengetabuan Sosial (IPS) (Bandung: Alfabeta, 2008), 46. 
dan menerapkannya dalam kehidupan. Kebermaknaan dari isi materi diarahkan pada bagaimana menyajikannya pada peserta didik. Berkenaan dengan hal tersebut berikut bentuk matrik kontribusi nilai pendidikan dari aktivitas kehidupan masyarakat Desa Sungai Rangas Ulu sebagai sumber belajar IPS.

\begin{tabular}{|c|c|c|}
\hline No & $\begin{array}{c}\text { Nilai } \\
\text { Pendidikan }\end{array}$ & Aktivitas Masyarakat \\
\hline 1 & Religius & $\begin{array}{l}\text { - Kegiatan pengaiian (yasinan) yang } \\
\text { dilaksanakan setiap minggu. Diikuti oleh } \\
\text { laki-laki/perempuan dari golongan muda } \\
\text { maupun tua. } \\
\text { - Menjalankan pengajian di rumah dengan } \\
\text { cara bergiliran dengan biaya dibebankan } \\
\text { ke seluruh anggota atas dasar } \\
\text { musyawarah. } \\
\text { - Partisipasi dalam perayaan hari besar } \\
\text { keagamaan. }\end{array}$ \\
\hline 2 & Etika & $\begin{array}{l}\text { - Proses pewarisan nilai budaya } \\
\text { berlandaskan kepercayaan bersifat } \\
\text { mistis. } \\
\text { - Penyajian sajen yang dilakukan setiap } \\
\text { tahun. } \\
\text { - Ketekunan untuk merefleksikan aktivitas } \\
\text { yang turun temurun. }\end{array}$ \\
\hline 3 & Sosial & 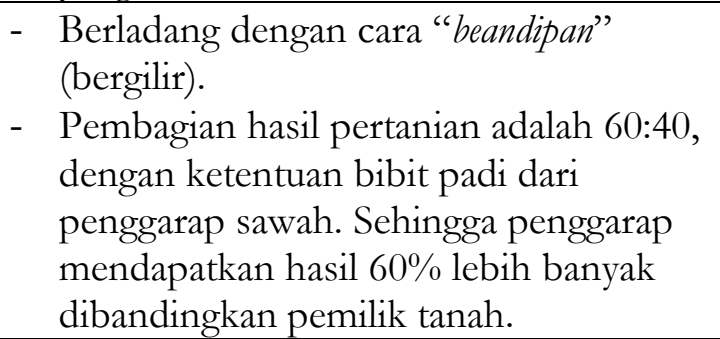 \\
\hline
\end{tabular}

Tabel 3 Matrik Kontribusi Nilai Pendidikan Aktivitas Kehidupan Masyarakat Banjar di Kelurahan Sungai Rangas Ulu sebagai Sumber Belajar IPS 
Pendidikan IPS dapat memberikan kontribusi yang cukup besar dalam mengatasi masalah sosial, sebab pendidikan IPS memiliki fungsi dan peran dalam meningkatkan sumber daya manusia untuk memperoleh bekal pengetahuan tentang harkat dan martabat manusia sebagai mahluk sosial, keterampilan menerapkan pengetahuan tersebut dan mampu bersikap berdasarkan nilai dan norma sehingga mampu hidup bermasyarakat. Guru dapat menciptakan kondisi yang kondusif untuk menumbuh kembangkan nilai-nilai anak menuju kearah pembentukan kepribadian peserta didik yang lebih baik. Pemilihan metode pembelajaran yang tepat dan efektif akan mampu meningkatkan nilai-nilai sosial pada diri peserta didik.

Guru dalam merancang pembelajaran harus mampu menciptakan iklim yang kondusif untuk tumbuh dan berkembangnya nilai-nilai, serta memberi kesempatan kepada peserta didik untuk melakukan refleksi nilainilai yang mereka miliki. Integrasi nilai-nilai dalam pendidikan IPS akan memberikan bekal kepada peserta didik dalam mengembangkan diri melalui berbagai keterampilan sosial dalam kehidupannya. Pendidikan IPS membekali peserta didik tentang pengetahuan, keterampilan, sikap, dan nilai, sehingga dapat membentuk citra diri peserta didik menjadi manusia yang memiliki jati diri yang mampu hidup di tengah masyarakat.

\section{Simpulan}

Masyarakat Desa Sungai Rangas Ulu secara umum dilatarbelakangi bermata pencaharian petani dan buruh. Namun, tidak sedikit pula dari mereka berdagang dan bertani. Sebagai masyarakat pedesaan (rural community) dominasi orang tua di masyarakat pedesaan tampak begitu jelas yang menjadikan masyarakat merasa ketergantungan dengan adanya orang tua atau sesepuh yang ada di masyarakat. Artinya, orang tua masih dijadikan sebagai role model bagi kehidupan bermasyarakat. Kendati demikian, pemuda tidak segan untuk berpartisipasi aktif pada kegiatan kemasyarakatan khususnya bersifat keagamaan.

Kegiatan keagamaan menjadi poros perekat hubungan antar masyarakat. Kegiatan rutin adalah pengajian (dikenal yasinan) yang 
dilaksanakan setiap minggu oleh tiga Rukun Tetangga (RT). Adapun kaitannya dengan nilai kehidupan aktivitas ini mengerucut kepada tiga nilai khusus, yakni; religius, etika, dan sosial. Bentuknya berupa; 1) Religius; aktivitas keagamaan yang dominan, 2) Etika; pewarisan nilai budaya secara turun temurun, dan 3) Sosial; manifestasi hubungan harmonis antar pemilik dan penggarap lahan pertanian. Kontribusi nilai pendidikan dan sumber belajar IPS adalah bentuk integrasi pendidikan nilai dalam pembelajaran IPS. Sumber belajar IPS harus dipandang sebagai satu kesatuan yang utuh dalam sebuah proses pembelajaran. Dengan demikian sumber belajar IPS bersifat praktis dan efektif dalam jiwa dan tindakan manusia serta melembaga secara objektif di dalam masyarakat. Implikasinya adalah sebagai daya pendorong atau prinsipprinsip yang menjadi pedoman dalam hidup. Pembelajaran yang dimaksudkan dapat menumbuhkembangkan nilai-nilai anak menuju kearah pembentukan kepribadian peserta didik yang lebih baik.

\section{Daftar Pustaka}

Abdullah, Burhanuddin, Radiansyah Radiansyah, and Ali Akbar. "Pendidikan Karakter Di Madrasah Aliyah Negeri (MAN) 2 Banjarmasin." Inferensi: Jurnal Penelitian Sosial Keagamaan 9, no. 2 (December 1, 2015): 537-60. https://doi.org/10.18326/infsl3.v9i2.537-560.

Agostinho, Shirley. "Naturalistic Inquiry in E-Learning Research." International Journal of Qualitative Methods 4, no. 1 (March 1, 2005): 13-26. https://doi.org/10.1177/160940690500400102.

Al Muchtar, Suwarma. Pendidikan Ilmu Pengetahuan Sosial (Dalam Ilmu Dan Aplikasi Pendidikan). Bandung: PT Imperial Bhakti, 2007.

Assyauqi, Moh Iqbal. "Pengembangan Media Pada Pembelajaran Kosa Kata Bahasa Arab Berbasis Komputer Menurut Konsep Teknologi Pembelajaran.” Jurnal Al Maqayis 2, no. 1 (September 26, 2014). https://doi.org/10.18592/jams.v2i1.186.

Buchari, Alma. Pembelajaran Studi Sosial. Bandung: Alfabeta, 2015.

Bungin, Burhan. Analisis Data Penelitian Kualitatif. Jakarta: Raja Grafindo Persada, 2008.

Bustanuddin, Agus. Agama Dalam Kehidupan Manusia; Pengantar Antropologi Agama. Jakarta: Grafindo Persada, 2006. 
Creswell, J. W. Research Design: Pendekatan Kualitatif, Kuantitatif, Dan Mixed. Yogjakarta: PT Pustaka Pelajar, 2010.

Depdiknas, Puskur Balitbang. Model Pembelajaran IPS Terpadu. Jakarta: Depdiknas, 2007.

Faslah, Roni. "Pemanfaatan Internet Dalam Pengembangan Konsep Ips Dan Implikasinya Terhadap Pembelajaran Bermakna." Jurnal Ilmiah Econosains 9, no. 2 (2011): 167-70. https://doi.org/10.21009/econosains.0092.07.

Fitri, Agus Zaenul. Pendidikan Karakter Berbasis Nilai Dan Etika Di Sekolah. Yogyakarta: Ar-Ruzz Media, 2012.

H.A.R, Tilaar. Paradigma Baru Pendidikan Nasional. Jakarta: Rineka Cipta, 2000.

J.W. Creswell. Research Design: Pendekatan Kualitatif, Kuantitatif, Dan Mixed. Yogyakarta: Pustaka Pelajar, 2010.

Kemendiknas. Pengembangan Pendidikan Budaya Dan Karakter Bangsa. Jakarta: Kementrian Pendidikan Nasional, 2010.

Kurdi, Musyarrafah Sulaiman. "Evaluasi Implementasi Desain Pendidikan Karakter Berbasis Pendekatan Humanistik."

Elementary: Jurnal Ilmiah Pendidikan Dasar 4, no. 2 (November 27, 2018): 125-38. https://doi.org/10.32332/elementary.v4i2.1243.

Lickona, Thomas. Character Matters. Jakarta: PT. Bumi Aksara, 2012.

L.W, Anderson, and Krathwohl D.R. Kerangka Landasan Untuk Pembelajaran, Pengajaran Dan Asesmen: Revisi Taksonomi Pendidikan Bloom. Yogyakarta: Pustaka Pelajar, 2010.

Mutiani, Mutiani. "Pemanfaatan Puisi Sebagai Sumber Belajar Ips Untuk Menumbuhkan Kesadaran Lingkungan Peserta Didik Di SMP Negeri 6 Banjarmasin." Jurnal Pendidikan Ilmu Sosial 24, no. 2 (April 7, 2016): 199-208.

Nasution. Metode Penelitian Naturalistik Kualitatif. Bandung: Tarsito, 2003. "Perubahan, Kebudayaan, Dan Agama: Perspektif Antropologi Kekuasaan | E-Jurnal Kajian Budaya (Online Journal of Cultural Studies)." Accessed July 2019. https://ojs.unud.ac.id/index.php/kajian/article/view/13874.

Pribadi, Yanwar. "Dinamika Hubungan Sosial-Keagamaan Pada Masyarakat Nelayan Di Karangantu Banten." TEOSOFI: Jurnal Tasawnf Dan Pemikiran Islam 7, no. 1 (June 2, 2017): 199-224. https://doi.org/10.15642/teosofi.2017.7.1.199-224. 
Shilla, Rhischa Assabet, Sentot Kusairi, and Arif Hidayat. "nalisis Penguasaan Konsep Hukum Newton tentang Gerak pada Implementasi Pembelajaran Berbasis Scientific Approach disertai Formative Assessment." Jurnal Pendidikan: Teori, Penelitian, dan Pengembangan 3, no. 8 (August 1, 2018): 1089-94. https://doi.org/10.17977/jptpp.v3i8.11485.

Somantri, Numan. Pembaharuan Pendidikan IPS. Bandung: Rosdakarya, 2001.

Spradley, James P. Metode Etnografi. Yogyakarta: Tiara Wacana, 2007. Subiyakto, Bambang, Syaharuddin Syaharuddin, and Gazali Rahman. "Nilai-Nilai Gotong Royong Pada Tradisi Bahaul Dalam Masyarakat Banjar Di Desa Andhika Sebagai Sumber Pembelajaran IPS." Vidya Karya 31, no. 2 (November 2, 2017). https://ppjp.ulm.ac.id/journal/index.php/JVK/article/view/39 93.

Subiyakto, Barnbang, and Djoko Suryo. "Pelayaran Sungai Di Kalimanta n Tenggara: Tinjauan Historis Tentang Transportasi Air Abad XIX = Inland Navigation in Southeast Kalimantan: A Historical Study of Water Transportationin The Nineteenth Century." Sosiobumanika 14, no. 2001 (2001). http://ilib.ugm.ac.id/jurnal/detail.php?dataId=3518.

Sugiyono. Metode Penelitian Kuantitatif Kualitatif Dan R\&D. Bandung: Alfabeta, 2014.

Wahab, Abdul Azis. Metode Dan Model-Model Mengajar Ilmu Pengetabuan Sosial (IPS). Bandung: Alfabeta, 2008. 
Bambang Subiyakto \& Mutiani 